\title{
Analysis of Factors Influencing the Dynamics of Labor Emigration: Case-Study of Ukraine
}

\author{
Wojciech Duranowski ${ }^{i}$, Yuriy Petrushenko ${ }^{i i}$, Anna Vorontsova ${ }^{i i i}$, \\ VERONIKA BARVINOK iv
}

\begin{abstract}
This article analyzes the results of foreign and domestic scientists in the field of labor migration and the factors of this phenomenon. Based on previous researches, factors have been grouped into four main categories, which include all areas of life of existing and potential migrants, such as economic and political, social and climatic.

Labor migration is constantly growing. Thus, according to the UN estimates, the number of migrant workers in the world in 2019 amounted to 272 million people, ie $3.5 \%$ of the population, compared to 2010 , the figure increased by $56.25 \%$. Such significant migration movements lead to a global imbalance in the labor market. This proves that the study of this type of migration as labor is relevant, especially the study of the factors that cause migratory flows.

The situation in Ukraine, along with world indicators, has a positive trend compared to previous years. Data from the State Statistics Service show an increase in labor migration by $44.4 \%$ between 2016 and 2019. The UN report estimates 5 million people in 2019 who found a job abroad and recognizes Ukraine as one of the leaders in the number of emigrants. This has led to significant losses of human capital (including "brain drain"). Thus, in 2019, Ukraine's losses from emigrants, including scientists and highly qualified specialists, are estimated at more than 1 billion dollars. Among the donor countries of Ukrainian migrants, the leaders are Poland, EU countries and Russia. This is mainly due to geographical factors and a higher economic level of development of states, compared to Ukraine.

The article will also analyze the main factors identified by the state as key in labor flows based on the Labor Flow Management Strategy for 2025, approved in 2019. In the course of the analysis of this strategy, the basic methods of struggle of the state from the viewpoint of the power were defined. Thus, wages and political instability have been identified as key factors that negatively affect migration. Based
\end{abstract}

${ }^{i}$ Wojciech Duranowski, Ph (in Economics), assistant professor of Department of Economy, University of Opole, Opole, Poland;

ii Yuriy M. Petrushenko, Doctor of Science (in Finance), Prof., Head of Department of International Economic Relations of Sumy State University;

${ }_{i i i}$ Anna S. Vorontsova, PhD (in Finance), senior lecture of the Department of International Economic Relations of Sumy State University;

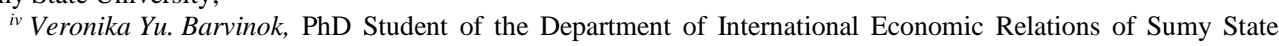
University.

This research is realized under the project funded by the Ministry of Education and Science of Ukraine (№ 0120U102001).

(C) В. Дурановскі, Ю. М. Петрушенко, А. С. Воронцова, В. Ю. Барвінок, 2020.

https://doi.org/10.21272/mer.2020.87.05

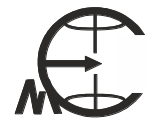

Механізм регулювання економіки, 2020, № 2 
В. Дурановскі, Ю. М. Петруиенко, А. С. Воронцова, В. Ю. Барвінок.

Аналіз факторів впливу на динаміку трудової еміграції: приклад України

on the obtained results, recommendations were developed for a more effective settlement of labor emigration issues in Ukraine.

Keywords: emigration, migration, migrant-worker, labor migration, factors influencing labor migration.

Abbreviations:

UN - United Nations;

EU - Europe Union.

УДК 331.556

JEL Codes: F22, J61

Introduction. Nowadays, labor migration takes the largest share of the migrants' flow in the world and Ukraine. According to the UN report [1], in 2019, 272 million people already migrated, while in 1990 this figure was $56.25 \%$ less - 153 million people. There is an acute problem regarding the emigration of the able-bodied population, mainly specialists and scientists in Ukraine. The loss of human capital as one of the main factors of the economy causes disturbances in the country's welfare. For example, the result of emigration from Ukraine is the ageing of the nation and the "brain drain". Ukrainian scholars have considered the nature of the emigration, but the problem has not been solved yet and needs a new vision. Thus, there is a need to review the nature of emigration in 2020 and identify the main factors that stimulate emigration labour flows. In the context of the study, mainly internal factors will be considered since in the future, these factors will be transferred to the Ukrainian reality.

Problem statement. The study of the migration phenomenon and its effects on various aspects of the national economies functioning is a global problem. Thus, it is studied by such world institutions as the UN, the European Commission, the International Organization for Migration and others. The definition of migration, its types and reasons have become the objects of numerous scientific studies, among which the following scientists can be distinguished: Ravenstein E. [2], Soloninko K. S. [3], Kurunova Yu. O. [6] and others. The works of Takhtarov K. A., Dorigo J. and Tobler V. [15] deal with the analysis of the main factors causing labour migration [14]. Malinovska O. A. [8, 11] and Pirozhkova S. [11] should be noted among the Ukrainian scientists who studied this phenomenon and made a significant contribution to the development of this scientific field. Scientists who were among the first to participate in the international project of the Population Department of the United Nations Economic Commission for Europe "External migration in Ukraine: reasons, consequences, strategies", which also identified the factors of external emigration in Ukraine.

Despite significant research in this topic, the issue of thorough systematization of specific factors influencing emigration in terms of different spheres of Ukrainians' life, remains quite relevant and requires more detailed study.

The purpose - to carry out a structural analysis regarding the nature and factors of labor emigration based on previous studies of domestic and foreign scholars, and to compare these factors with the labor emigration dynamics in Ukraine.

Results of the research. First of all, the study of labor emigration begins with definitions of the basic concepts that form this phenomenon. The first definition of "migration", actively used by scientists, was proposed by Professor E. Ravenstein - "permanent or temporary change of residence" [2]. Recently, the issue of migration has become acute for countries around the world, which in most cases is related to the economic and social aspect of this phenomenon, namely: labor migration.

Labor migration is not a new phenomenon and has a certain history. There are many concepts of "labor migration". One of the clearest and meaningful definitions of this 
Wojciech Duranowski, Yuriy Petrushenko, Anna Vorontsova, Veronika Barvinok. Analysis of Factors Influencing the Dynamics of Labor Emigration: Case-Study of Ukraine

phenomenon in our opinion is presented in the textbook of Soloninko K., where the author determined that "labor migration" is a movement caused by certain economic, social, political or other reasons, namely the working population from some countries (regions) to others during more than one year" [3]. This idea is complemented by N. N. Liventsev, who emphasizes that "international labor migration is the movement of employees across borders in search of work" [4].

Based on the migration phenomenon, a separate term is distinguished for its subject, i. e. the person directly involved in the migration - "migrant worker". According to the definition of the ILO Convention 97 (1949), "a migrant worker is a person who migrates for employment at the expense of another person" [5]. While the UN expands this concept and the calculations take into account not only migrants employed abroad in this period but also those who have experience of migration. [1].

Kurunova Yu. O. identified this phenomenon as "the most common type of economic migration" since a significant proportion of migrants $74 \%$ in the world, are people of working age (20-64 years), i.e. migrant workers (according to the 2020 report of the International Organization for Migration) [6].

The main reason for the study of labor migration among economists is the significant economic impact of this phenomenon starting from one country's welfare to the world economy as a whole since modern labor migration is one of the subsystems of international economic relations in the country [6].

Migration provides feedback, distinguishing two basic concepts: immigration (entry into the country of destination) and emigration (leaving the country of origin). In scientific literature, emigration is understood as "relocation (voluntary or forced) to another country for permanent or temporary residence, which has economic, religious, political reasons" [7].

Based on the above terms, it should be emphasized that labor migration has certain reasons and preconditions. Migrant workers have a certain motivation related to employment, which is a factor to change the status of a citizen to the migrant.

Before starting the analysis regarding the reasons of migration, we turn to the monograph of Shymansjka K. V., where the concept of "factor" was used as the most meaningful definition of the basis to form migration reasons (motives). This is explained by the fact that it is a set of factors that are different in features, origin, intensity of action, but have a heterogeneous impact on the formation of migration processes among the country's citizens" [7].

The main factors that cause the international migration of labor force, in the scientific literature are usually grouped into the following main categories: economic, political, natural and social (psychological). These factors and reasons of labor migration are grouped in Table 1.

Economic factors of labor migration are usually caused by the search for new more lucrative jobs abroad since the employment relationship between the employer and the employee is primarily related to monetary and financial relations (wages, bonuses, etc.). In most cases, this factor plays a significant role for developing countries and CIS countries that have a financial need to emigrate to developed countries. Citizens are dissatisfied with wages and working conditions compared to developed countries, and this dissatisfaction is especially prevalent among specialists with higher education and experience seeking career growth. For example, immigrants to the United States are 1) mid-level and senior IT specialists who have reached the maximum possible career growth and salary level in the homeland; 2) workers of narrowly focused specialities who are unemployed due to the oversupply of the labor market. 
В. Дурановскі, Ю. М. Петруиенко, А. С. Воронцова, В. Ю. Барвінок.

Аналіз факторів впливу на динаміку трудової еміграції: приклад України

Table 1

\begin{tabular}{|c|c|}
\hline $\begin{array}{c}\text { Factors of labor } \\
\text { migration }\end{array}$ & Reasons \\
\hline Economic & $\begin{array}{l}\text { - supply and demand in the labor market; } \\
\text { - the weak economic development of the country (reliability of the banking system, } \\
\text { infrastructure development, etc.); } \\
\text { - high unemployment rate (more than } 2 \% \text { ); } \\
\text { - unsatisfactory/inadequate wage level, which is relatively lower than in developed } \\
\text { countries; } \\
\text { - lack of career growth; } \\
\text { - low technical level of working conditions; } \\
\text { - incomplete / absent democratization of labor relations; } \\
\text { - high level of labor income taxation; } \\
\text { - lack of employee's insurance; } \\
\text { - devaluation of the national currency; } \\
\text { - strengthening the social orientation of the economy; } \\
\text { - globalization and integration of the origin-country }\end{array}$ \\
\hline Political & $\begin{array}{l}\text { - war; } \\
\text { - discrimination against people depending on their political views; } \\
\text { - opening borders to developed countries; } \\
\text { - the tense political situation in the country; } \\
\text { - discrimination of certain social groups by the state; } \\
\text { - political persecution; } \\
\text { - oppression of religious groups by the state; } \\
\text { - lack of trade union committees }\end{array}$ \\
\hline $\begin{array}{l}\text { Social } \\
\text { (psychological) }\end{array}$ & $\begin{array}{l}\text { - unsatisfactory living conditions, welfare; } \\
\text { - change of state borders; } \\
\text { - unsatisfactory working conditions (lack of labor rights protection, underdeveloped } \\
\text { corporate culture); } \\
\text { - lack of conditions for the full realization of potential and ambitions; } \\
\text { - religious reasons (discrimination of religious minorities, etc.); } \\
\text { - national reasons (oppression of national minorities); } \\
\text { - cultural reasons (ethnic, mentality); } \\
\text { - family reasons (change of the workplace of the spouse) }\end{array}$ \\
\hline $\begin{array}{l}\text { Natural } \\
\text { climatic }\end{array}$ & $\begin{array}{l}\text { - the higher level of environmental protection; } \\
\text { - environmental pollution; } \\
\text { - attractive climate; } \\
\text { - natural disasters (volcanic eruptions, earthquakes); } \\
\text { - natural disasters (hurricanes, floods, etc.) }\end{array}$ \\
\hline
\end{tabular}

Source: Table is based on: [3], [4], [6], [7] [7], [9], [10], [Ошибка! Источник ссылки

не найден.], [11], [13]

Takhtarova K. A. highlights the peculiar trends of the modern labor market, such as: "standardization of conditions and work of people in different countries, internationalization of labor reproduction requirements, the democratization of labor relations, strengthening the social orientation of the economy" [14].

Political factors are those that caused the first migration processes in the world. Known mass "waves" of migration are observed during the First and Second World Wars. The tense political situation in the country, leading to discrimination against certain groups of citizens, 
Wojciech Duranowski, Yuriy Petrushenko, Anna Vorontsova, Veronika Barvinok. Analysis of Factors Influencing the Dynamics of Labor Emigration: Case-Study of Ukraine

forces them to look for employment abroad. These reasons are also noted by scholars Dorigo J. and Tobler W., who highlight wars, political persecution, discrimination [15]. Some reasons for this category become socio-psychological since they create significant discomfort for the employee in terms of social relations and psychological perception.

The next group of factors began to play an important role in the 21st century when human values have been significantly changed. Many scholars point out social or psychological reasons for migration. First, social factors include the development of the public sphere in the country. Dorigo J. and Tobler W. [15] mention "low level of health care, religious and political freedom, health insurance, education, development industry among the social factors". Secondly, Takhtarova K. A. defines psychological factors as those which are formed on the ground of modern universal values [14]. Another scientist Yevdokimov A. I. [16] point out economic factors but also mention the importance of ethnic, cultural and family reasons of migration. Kislitsina O. V. [12] defines that the decisions regarding labor migration is caused by many subjective reasons in the context of globalization, i. e. "the possibility of personal realization through international social mobility".

The emergent category of factors contributing to labor migration caused by natural disasters. However, this category includes the reasons identified by Dorigo J. and Tobler W., namely, environmental pollution, attractive climate, etc. [15].

Having identified the main factors that cause migration, we consider the situation of labor emigration in Ukraine today.

For Ukraine, labor migration (mostly emigration) is a common phenomenon among the working population. It provides better employment with higher wages and the possibility of further self-realization in better working conditions and welfare in general. Various mobility programs and work programs abroad are actively offered to students. These are usually seasonal jobs, but the share of migrant students never comes back home.

State statistics provide data on 1.3 million migrants, but experts give higher figures, namely from 2 to 4 million migrant workers [17]. On the part of the state, the main reason for the prevalence of this phenomenon is the high level of unemployment and the search for a better life abroad $[13,21]$.

UN experts report that Ukraine is among the ten countries with the largest number of migrant workers [1]. This situation has developed historically since Ukraine lost $15-20 \%$ of its intellectual potential as a result of emigration in the 1990s. During the reforms (1991-2000) $70-80 \%$ of its mathematicians left the country, $50 \%$ of theoretical physicists who continue their activities abroad. Ukraine's annual losses from the departure of scientists and highly qualified specialists are estimated at more than 1 billion US dollars [18]. The most important problem for emigration countries is the irreversible loss of skilled labor.

According to the State Statistics Service of Ukraine, in 2019 the flow of emigrants is estimated at 554,520 thousand people. The general dynamics of emigration from Ukraine is in Figure 1. 
В. Дурановскі, Ю. М. Петрушенко, А. С. Воронцова, В. Ю. Барвінок.

Аналіз факторів впливу на динаміку трудової еміграції: приклад України



Figure 1. Dynamics of population emigration from Ukraine, 2003-2019, persons Source: [17].

As we can see in the graph, the trends of emigration flows in Ukraine have been changed significantly over the last 15 years. Since 2003, there have been about 700,000 emigrants in Ukraine, who tended to decline and reached the first peak and decreased by $19 \%(609,902$ thousand people) in 2009. Economic factors negatively affected the emigration rate: after the international banking crisis of 2008, which began with the United States, the national currency against the dollar rose and improved the country's economic climate. In the period from 2010 to 2014 , there was a slow increase. In 2014, political instability began in the country - the occupation of the Autonomous Republic of Crimea and the beginning of the RussianUkrainian war in Donbas. The unfavourable political situation reduced the share of workers who worked in Russia. In 2017, after the introduction of the visa-free regime, the majority of the Ukrainian population emigrated in search of work in Europe, mainly in Poland. It should be noted that during 2014-2018, political factors became decisive, both positively and negatively for emigration. The end of 2019 and the beginning of 2020 significantly stimulated the reduction of migration flows of the Coronavirus disease outbreak (COVID-19), which became a natural and climatic factor both in the world and in Ukraine. Thus, the main factors influencing emigration in Ukraine are economic and political, and for the last year also natural ones.

The State Statistics Service claimed that in 20191.3 million people emigrated for employment (based on the calculation of people who go abroad for employment at least once in the last 2.5 years) [13].

The political disruption and economic crisis appeared in the country since 2014 has led to a decrease in the influx of emigrants to Russia. However, in recent years, migration from Ukraine has been variable, in 2020 Poland and other EU countries will replace Russia as the main destination country. Migration to the Russian Federation is caused by historical factors and began after the Soviet Union collapsed, which is related to political and social aspects. The deterioration of the situation after the change of government in 2014 increased the demand among Ukrainians for jobs in Poland, due to higher wages, geographical proximity, as well as the visa-free regime, access to this labor market increased interest among Ukrainians $[19,20]$. 
Wojciech Duranowski, Yuriy Petrushenko, Anna Vorontsova, Veronika Barvinok. Analysis of Factors Influencing the Dynamics of Labor Emigration: Case-Study of Ukraine

One of the indicators that help to confirm the experts' opinions on the increase in emigration to Poland and other EU countries is the cash flow to Ukraine from the represented countries [19]. Matthias Lucke and David Saha expressed this opinion in their work. The report states that the geographical composition of remittances reflects the shifts in the countries of migrants' destination from Russia to Poland and other EU member states (Fig. 2).

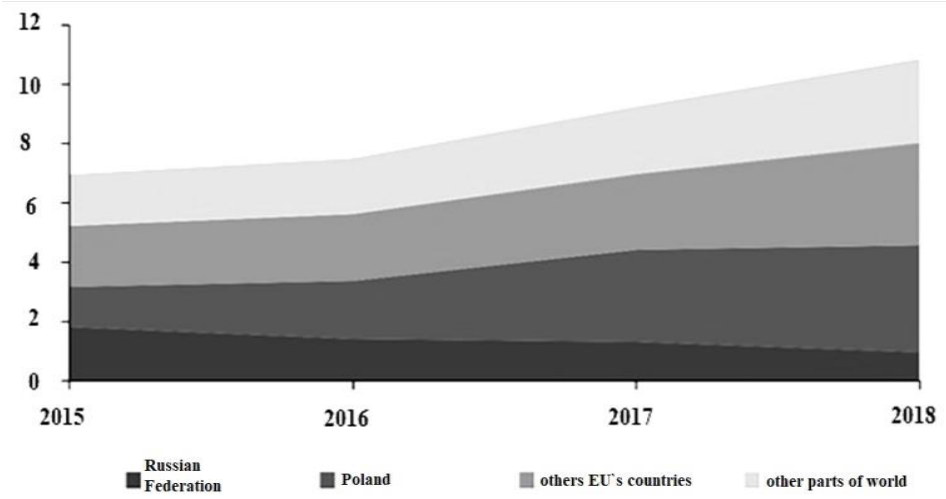

Figure 2. - Net cash returns to Ukraine by recipient countries, USD million Source: [18].

In 2018, more than two-thirds of remittances came from EU member states, which was compared to half of 2015 (Fig. 2). Poland replaced Russia as the largest country with a single source, accounting for a third of remittances in 2018. [19]

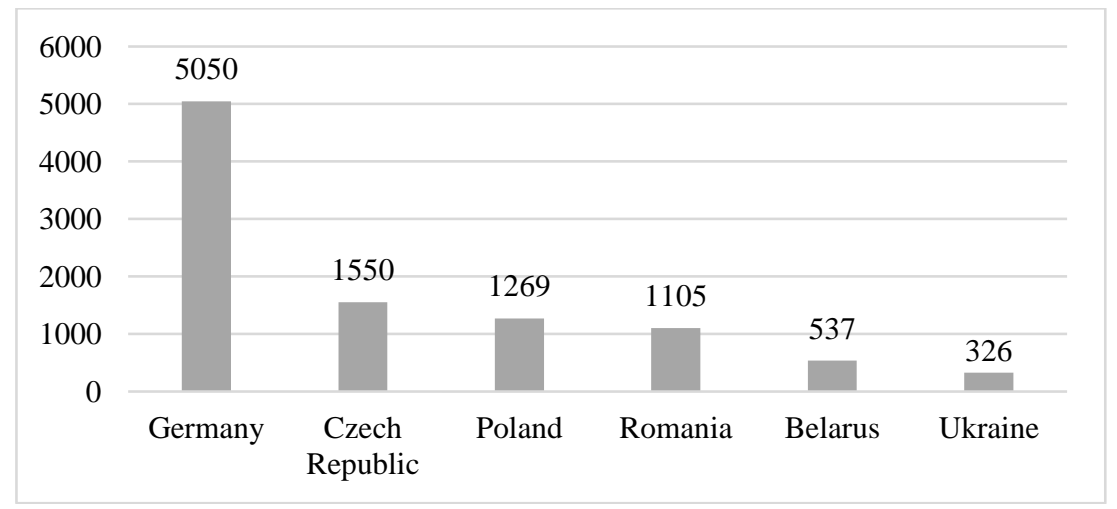

Figure 3. - Average monthly wages in Ukraine and the leading countries of Ukrainian emigration in 2017, USD Source: [18]

The difference between the level of wages in Ukraine and other developed countries always differed significantly. After several political and economic crises, this development increased especially. Although the average monthly wage increases every year, the state still fails to reach at least the minimum level. For example, in 2015 , after the economic crisis, the 
lowest wage was \$ 192 and rose to \$ 326 in 2018, which is $25 \%$ and $10 \%$ of wages in the Czech Republic, Poland and Germany, respectively (Fig. 3).

The Cabinet of Ministers of Ukraine approved the Strategy of State Migration Policy until 2025 to regulate migration issues. This strategy primarily includes increasing funding, improving national legislation in line with international standards (visa liberalization with the EU) and promoting socio-economic development of the country [21].

The Ukrainian government constantly tries to improve the economic and political aspects of citizens' lives to reduce labor emigration. However, these two factors are not the main ones, and their partial elimination does not significantly reduce the emigration flow of human capital. The state should pay attention to the regulation of the environmental and social sectors. Improvement of the citizens' physical and psychological well-being will also reduce the overall tension and increase the demand for employment opportunities in Ukraine.

Conclusions and prospects of further research. Labor migration is not a new phenomenon today because historically it existed at all stages of human development, but, nowadays, in the context of globalization, it is only intensifying. For this reason, experts and scholars actively study the nature of this phenomenon, especially emigration since its significant volume has economic and political influence, which destabilizes the situation in the world. Identification and review of the main factors influencing migration contribute to the state's ability to gain control over this phenomenon. It is necessary to develop effective ways to counteract the emigration of able-bodied people, to reconsider the causal links in Ukraine, as one of the most typical countries-emigrants. The analysis of literature sources allowed to identify four main factors influencing labor migration. They include economic, political, social (psychological) and climatic factors. The Ukrainian authorities identify the first two as the main reasons for emigration, and actively try to improve them (for example, the visa-free regime), but it leads to a reorientation of labor flow. However, the positive dynamics of labor migration indicates an inexpedient vector of management of migration flows by the state. For these reasons, it is worth paying attention to two other segments of Ukrainian life. An outbreak of coronavirus disease (COVID-19) showed that climatic factors also have a significant effect on dynamics. Moreover, if all four factors of migration are evenly improved, human capital will remain in Ukraine. First of all, it depends on state policy, which significantly affects the citizens' welfare and well-being.

In the future, the authors plan to analyze in more detail each group of factors (especially social and climatic) that affect labor emigration to the EU (Poland separately) and Russia. Based on the available statistics, a regression analysis will be conducted and the main factors of labor emigration to the EU and Poland will be defined.

\section{Reference}

1. World Migration Report 2020 [International Organization for Migration] Retrieved from https://publications.iom.int/system/files/pdf/wmr_2020.pdf

2. Ravenstein, E. G. (1871). The Birthplaces of the People and the Laws of Migration. Great Britain, GB: Gensus of the British Isles.

3. Soloninko, K. (2008). Mizhnarodna trudova mighracija [Mizhnarodna ekonomika] Kyjiv : Kondor.

4. Shymansjka, K. (2017). Mighracija ljudsjkykh resursiv $v$ umovakh gheoekonomichnykh transformacij: reghionaljnyj vymir (Monoghr.tekh.spec.). Zhytomyrsjkyj Derzhavnyj Tekhnologhichnyj Universytet, Zhytomyr.

5. Konvencija pro pracivnykiv-mighrantiv (2020, Chervnja 5). Verkhovna Rada. Konvencija MOP vid 1 lypnja 1949 r. \# 97. Retrieved from http://zakon5.rada.gov.ua/laws/show/ 993_159 
Wojciech Duranowski, Yuriy Petrushenko, Anna Vorontsova, Veronika Barvinok. Analysis of Factors Influencing the Dynamics of Labor Emigration: Case-Study of Ukraine

6. Kurunova, Yu. (2015). Mizhnarodna mighracija robochoji syly jak chynnyk ekonomichnogho rozvytku krajin [Odesjkyj nacionaljnyj universytet imeni I.I. Mechnykova] Retrieved from https://www.lnu.edu.ua/wp-content/uploads/2015/12/dis_kurunova.pdf

7. Bakaev, O., Rymarenko, Ju. \& Shemshuchenko, Ju. (Red.). (2004). Ukrajinsjka encyklopedija im. M. $P$. Bazhana, Kyjiv : Nac. akad. nauk Ukrajiny.

8. Malynovsjka, O. A. \& Smolij, V. A. (2009). Mighracija zovnishnja. [Encyklopedija istoriji Ukrajiny] Kyjiv: Naukova dumka.

9. Massey, D. (2015). A Missing Element in Migration Theories [Migration Letters]. Retrieved from http://www.tplondon.com/journal/index.php/ml/article/viewFile/568/411

10. Cebula, R. J. (2006). Determinants of net interstate migration 2000-2004 (Ed.), Journal of Regional Analysis and Policy (pp. 116-123) Retrieved from https://www.researchgate.net/profile/Richard_Cebula2/publication/238214665_Determinants_of_Net _Interstate_Migration_2000-2004/links/02e7e5224ae4ced5eb000000.pdf.

11. Pirozhkov, S. Malinovskaya, O. \& Homra, A. (2003). Vneshnie trudovye migracii v Ukraine: social'noekonomicheskij aspekt [Sovet nacional'noj bezopasnosti i oborony Ukrainy], Kiev.

12. Kruk, O. V. (2020). Mizhnarodna trudova mighracija ta jiji vyklyky dlja Ukrajiny [Teorija ta praktyka derzhavnogho upravlinnja i miscevogho samovrjaduvannja]. Retrieved from http://el-zbirndu.at.ua/2020_1/18.pdf

13. Sushko, I., Kuljchycjka, K. \& Minich, R. (2019). Mify i fakty pro ukrajinsjku trudovu mighraciju do krajin Vysheghradu [GhO «Jevropa bez bar'jeriv»]. Retrieved from https://europewb.org.ua/wpcontent/uploads/2019/04/Mify_trud_migrac.pdf.

14. Takhtarova, K. A. (2015). Rozvytok trudovoji mighraciji v systemi mizhnarodnykh trudovykh komunikacij: metodologhichnyj aspect [Visnyk Pryazovsjkogho derzhavnogho tekhnichnogho universytetu]. Retrieved from http://nbuv.gov.ua/UJRN/VPDTU_ek_2015_29_8

15. Dorigo, G. \& Tobler, W. (2005). Push and pull migration law [Human Migration Guide] United States, US: National Geographic.

16. Evdokymov, A. Y. (2009). Mezhdunarodnble ekonomycheskye otnoshenyja [Myrovaja эkonomyka] Moskva, M: Yzd-vo SPbGhUЭF.

17. Mighracijnyj rukh naselennja (2020, June) [Derzhavna sluzhba statystyky] Retrieved from http://www.ukrstat.gov.ua/operativ/operativ2018/ds/mr/mr_u/mr1218_u.html.

18. Jakymy je realjni masshtaby trudovoji mighraciji z Ukrajiny do JeS (2020, February 11). [Ekonomichna pravda] Retrieved from https://www.epravda.com.ua/publications/2020/02/11/656895

19. Lücke, M. \& Saha, D. (2019, December). Labour migration from Ukraine: Changing destinations, growing macroeconomic impact. Berlin/Kyiv, B/K: German Advisor Group. Retrieved from https://www.german-economic-team.com/ukraine/wpcontent/uploads/sites/7/GET_UKR_PS_02_2019_en.pdf.

20. Skoczyńska-Prokopowicz B. (2018). Labor emigration from Ukraine to Poland: history and current status [Journal of the Belarusian State University Sociology], 151-161. Retrieved from http://elib.bsu.by/handle/123456789/205746.

21. Pro skhvalennja Strateghiji derzhavnoji mighracijnoji polityky Ukrajiny na period do 2025 roku (2020) [Kabinet Ministriv Ukrajiny. Kyjiv]. Retrieved from https://zakon.rada.gov.ua/laws/show/482-2017-\%D1\%80.

Manuscript received 10 May 2020

Анализ факторов, влияющих на динамику трудовой эмиграции: пример Украины

$$
\begin{gathered}
\text { ВОЙЦЕХ ДУРАНОВСКИ", } \\
\text { ЮРИЙ НИКОЛАЕВИЧ ПЕТРУШЕНКО } \\
\text { АН , } \\
\text { АНА СЕРГЕВНА ВОРОНЦОВА } \\
\text { ВЕРОНИКА ЮРЬЕВНА БАРВИНОК } \\
\text {,**** }
\end{gathered}
$$


В. Дурановскі, Ю. М. Петрушенко, А. С. Воронцова, В. Ю. Барвінок.

Аналіз факторів впливу на динаміку трудової еміграції: приклад України

* кандидат экономических наук, доцент кафедры экономики Опольського університета, plac Kopernika, 11A, 45-040 г. Ополе, Польща

** доктор экономических наук, професор, заведуюший кафедры международных экономических отношений Сумского государственного университета, ул. Петропавловская, 57, Сумы, 40000, Украина, e-mail:wduranowski@gmail.com

**** кандидат экономических наук, старший научный сотрудник, ассистент кафедры международных экономических отношений Сумского государственного университета, ул. Петропавловская, 57, Сумьл, 40000, Украина, e-mail: a.vorontsova@uabs.sumdu.edu.ua

**** аспирант кафедры международных экономических отношений

Сумского государственного университета,

ул. Петропавловская, 57, 40000 Сумы, Украина

e-mail:v.barvinok@uabs.sumdu.edu.com

Данная статья анализирует результаты зарубежных и отечественных ученых в вопросе трудовой миграции и факторов возникновения данного явления. На основе предыдущих исследований были сгруппированы факторы в четыре основные категории, которые включают все сферы жизни существующих и потенциальных мигрантов, такие как: экономические и политические, социальные и природно-климатические.

Миграция с целью трудоустройства постоянно растет. Так, по оценкам ООН, численность трудовых мигрантов в мире в 2019 году составила 272 млн. человек, то есть 3,5\% населения, по сравнению с 2010 годом этот показатель вырос на 56,25\%. Такие весомые миграционные движения влекут мирового дисбаланса конъюнктуры трудового рынка. Это доказывает, что изучение такого вида миграции, как трудовая является актуальным, особенно исследования факторов, вызывающих миграционные потоки.

Ситуация в Украине на ряду с мировыми показателями имеет положительную тенденцию по сравнению с предыдущими годами. Данные Службы Государственной статистики Украины демонстрируют увеличение трудовой миграции на 44,4\% в промежутке между 2016 и 2019 годами. В докладе ООН начисляется 5 млн. человек в 2019 году, которые нашли место работы за рубежом и определяет Украину как одного из лидеров стран по численности эмигрантов. Это привело к значительным потерям человеческого капитала (в том числе «утечки мозгов»). Так, в 2019 году потери Украины от эмигрантов, среди которых ученые и высококвалифицированных специалисты оцениваются более 1 млрд. долл. США. Среди стран-доноров украинских мигрантов, лидерами являются Польша, страны ЕС и Россия. Преимущественно это обусловлено географическими факторами и высоким экономическим уровнем развития государств, по сравнению с Украиной

В статье также будут проанализированы основные факторы, которые определены государством, как ключевые в трудовых потоках на основе Стратегии управления трудовыми потоками на 2025 году, утвержденной в 2019 году. В ходе анализа данной стратегии были определены основные методы борьбы государства с точки зрения власти. Таким образом, ключевыми факторами, которые негативно влияют на миграцию, определенные оплата труда и политическая нестабильность. На базе полученных результатов были разработаны рекомендации для более эффективного урегулирования вопросов трудовой эмиграции в Украине.

Ключевые слова: эмиграция, миграция, работник-мигрант, трудовая миграция, факторы влияния на трудовую миграцию.

Аббревиачия:

$\mathrm{OOH}$ - Организация Объединённых Наций; 
Wojciech Duranowski, Yuriy Petrushenko, Anna Vorontsova, Veronika Barvinok. Analysis of Factors Influencing the Dynamics of Labor Emigration: Case-Study of Ukraine

ЕС - Европейский Союз.

Mechanism of Economic Regulation, 2020, No 2, 61-73 ISSN 1726-8699 (print)

Аналіз факторів впливу на динаміку трудової еміграції: приклад України

ВОЙЦЕХ ДУРАНОВСКІ

ЮрІй МИКОЛАЙОВИч ПЕТРУШЕНКо ${ }^{* *}$

АННА СЕРГЇ̈НА ВОРОНцОВА ${ }^{* * *}$,

ВЕРОНІКА ЮРІЇВНА БАРВИНОК

* кандидат економічних наук, дочент кафедри економіки Опольського університета, м. Ополе, Польща

email:wduranowski@gmail.com

** доктор економічних наук, професор, завідувач кафедри міжнародних економічних відносин

Сумського державного університету,

email: yuriy.petrushenko@gmail.com

**** кандидат економічних наук, старший викладач кафедри міжнародних економічних відносин

Сумського державного університету,

email: a.vorontsova@uabs.sumdu.edu.ua

**** аспірант кафедри міжнародних економічних відносин Сумського державного університету, e-mail:v.barvinok@uabs.sumdu.edu.com

Дана стаття аналізує наукові результати зарубіжних та вітчизняних робіт у питанні трудової міграції та факторів виникнення даного явища. На основі попередніх досліджень були згруповані чинники в чотири основні категорії, які включають всі сфери життя існуючих та потенційних мігрантів, такі як: економічні та політичні, соціальні та природно-кліматичні.

Міграція з метою працевлаштування постійно зростає. Так, за оцінками $\mathrm{OOH}$, чисельність трудових мігрантів у світі за 2019 році становила 272 млн. осіб, тобто 3,5\% населення, у порівнянні із 2010 роком показник зріс на 56,25 \%. Такі вагомі міграційні рухи призводять до світового дисбалансу кон'юнктури трудового ринку. Це доводить, що вивчення такого виду міграції, як трудова $є$ актуальним, особливо дослідження факторів, що спричиняють міграційні потоки.

Ситуація в Україні, на ряду зі світовими показниками, має позитивну тенденцію, порівняно 3 попередніми роками. Дані Держстатики демонструють збільшення трудової міграції на 44,4\% у проміжку між 2016 та 2019 роками. У доповіді ООН, показник становить 5 млн. осіб у 2019 році, що знайшли місце роботи закордоном та визнає Україну, як одного із лідерів країн за чисельністю емігрантів. Це призводить до значних втрат людського капіталу (в тому числі «відтоку мізків»). Так, у 2019 році втрати України від емігрантів серед яких науковці та висококваліфікованих фахівці оцінюються понад 1 млрд. дол. США. Серед країн-донорів українських мігрантів, лідерами є Польща, країни $Є \mathrm{C}$ та Росія. Переважно це зумовлено географічними факторами та вищим економічним рівнем розвитку держав, порівняно із Україною.

У статі також будуть проаналізовані основні фактори, які визначені державою, як ключові у трудових потоках на основі Стратегії управління трудовими потоками на 2025 рік, що схвалена у 2019 році. В ході аналізу даної стратегії були визначені основні методи боротьби держави з точки зору влади. Таким чином, ключовими факторами, які негативно впливають на міграцію, визначені оплата праці та політична нестабільність. На базі отриманих результатів були розроблені рекомендації щодо ефективного регулювання питань трудової еміграції в Україні.

Ключові слова: еміграція, міграція, працівник-мігрант, трудова міграція, фактори впливу на 
трудову міграцію.

Абревіаиіï:

ООН - Організація Об’єднаних Націй;

ЄC - Європейський Союз.

Table: 1; Figures: 3; References: 21

JEL Codes: F22, J61

Language of the article: English

References

1. World Migration Report 2020 [Electronic resource] : International Organization for Migration. Accessed mode: https://publications.iom.int/system/files/pdf/wmr_2020.pdf - Заголовок з екрану. (Актуально на 06.06.2020 р.).

2. Ravenstein, E. G. The Birthplaces of the People and the Laws of Migration. Great Britain: Gensus of the British Isles. $-1871 .-56 \mathrm{p}$.

3. Солонінко, K. Міжнародна економіка : навч. посіб. / К. Солонінко. - Київ : Кондор. - 2008. $380 \mathrm{c}$.

4. Шиманська, $K$. Міграція людських ресурсів в умовах геоекономічних трансформацій: регіональний вимір : Монографія / К. Шиманська // Житомир : Житомирський Державний Технологічний Університет. - 2017. - 588 с.

5. Конвенція про працівників-мігрантів. Конвенція МОП від 1 липня 1949 r. № 97 [Електронний peсурс] : Верховна Рада. - Режим доступу : http://zakon5.rada.gov.ua/laws/show/ 993_159. (Актуально на 06.06.2020 р.).

6. Курунова, Ю. Міжнародна міграція робочої сили як чинник економічного розвитку країн Одеський національний університет імені І.І. Мечнікова [Електронний ресурс] / Ю. Курунова. - Режим доступу : https://www.lnu.edu.ua/wp-content/uploads/2015/12/dis_kurunova.pdf. (Актуально на 06.06.2020 р.).

7. Бакаев, О. Міграція / О. Бакаев, Ю. Римаренко, Ю. Шемшученко // Київ : Українська енциклопедія ім. М. П. Бажана. - 2004. — 768 с.

8. Малиновська, О. А. Міграція зовнішня / О. А. Малиновська // Енциклопедія історії України : у 10 т. / редкол.: В. А. Смолій (голова) та ін. ; Інститут історії України НАН України. — К. : Наук. думка, 2009. — Т. 6 : Ла — Mi. — 784 с. : іл. — ISBN 978-966-00-1028-1.

9. Massey, D. A. Missing Element in Migration Theories [Electronic resource] : Migration Letters. Accessed mode: http://www.tplondon.com/journal/index.php/ml/article/viewFile/568/411. (Актуально на 06.06.2020 p.).

10. Cebula, R. J. Determinants of net interstate migration 2000-2004 [Electronic resource]: Journal of Regional Analysis and Policy. - Accessed mode: https://www.researchgate.net/profile/Richard_Cebula2/publication/238214665_Determinants_of_Net _Inter state_Migration_2000-2004/links/02e7e5224ae4ced5eb000000.pdf. (Актуально на 06.06.2020р.).

11. Vneshnye trudovie myghracyy v Ukrayne : socyaljno-ekonomycheskyj aspekt / S. Pyrozhkov, E. Malynovskaja, A. Khomra // Sovet nac. bezopasnosty y oboronы Ukraynы, Nacyonaljnыj yn-t problem mezhdunar. bezopasnosty. - Kyev : Nac. yn-t problem mezhdunar. bezopasnosty, 2003. $133 \mathrm{~s}$.

12. Крук, O.B. Міжнародна трудова міграція та їі виклики для України - Теорія та практика державного управління і місцевого самоврядування [Електронний ресурс]: / О.В. Крук. Режим доступу: http://el-zbirn-du.at.ua/2020_1/18.pdf. (Актуально на 06.06.2020р.).

13. Сушко, I. Міфи і факти про українську трудову міграцію до країн Вишеграду - ГО «Європа без бар'єрів» [Електронний ресурс] / І. Сушко, К. Кульчицька, Р. Мініч. - Режим доступу: https://europewb.org.ua/wp-content/uploads/2019/04/Mify_trud_migrac.pdf. (Актуально на 06.06.2020 p.). 
Wojciech Duranowski, Yuriy Petrushenko, Anna Vorontsova, Veronika Barvinok. Analysis of Factors Influencing the Dynamics of Labor Emigration: Case-Study of Ukraine

14. Тахтарова, K.A. Розвиток трудової міграції в системі міжнародних трудових комунікацій: методологічний аспект - Вісник Приазовського державного технічного університету [Електронний ресурс] / К.А. Тахтарова. - Режим доступу: http://nbuv.gov.ua/UJRN/VPDTU_ek_2015_29_8. (Актуально на 06.06.2020р.).

15. Dorigo, G., Tobler, W. Push and pull migration laws; Human Migration Guide. United States: National Geographic. - 2005. -22 p.

16. Евдокимов, А. И. Международные экономические отношения / А. И. Евдокимов // Мировая экономика. Москва: Изд-во СПбГУЭФ. - 2009 - 79 с.

17. Державна служба статистики [Електронний ресурс]. - Режим доступу: http://www.ukrstat.gov.ua/operativ/operativ2018/ds/mr/mr_u/mr1218_u.html. (Актуально на 06.06.2020 р.). - Заголовок з екрану.

18. Економічна правда. [Електронний ресурс]. https://www.epravda.com.ua/publications/2020/02/11/656895.

19. Lücke, M., Saha, D. Labour migration from Ukraine: Changing destinations, growing macroeconomic impact. [Electronic resource]: German Advisor Group. - Accessed mode : https://www.german-economic-team.com/ukraine/wpcontent/uploads/sites/7/GET_UKR_PS_02_2019_en.pdf. (Актуально на 06.06.2020р.).

20. Skoczyńska-Prokopowicz B. Labor emigration from Ukraine to Poland: history and current status [Electronic resource] : Journal of the Belarusian State University. Sociology. - Accessed mode : http://elib.bsu.by/handle/123456789/205746.

21. Про схвалення Стратегії державної міграційної політики України на період до 2025 року. [Електронний ресурс] : Кабінет Міністрів України. - Режим доступу: https://zakon.rada.gov.ua/laws/show/482-2017-\%D1\%80. (Актуально на 06.06 .2020 р.). Заголовок з екрану. 